\title{
A Research Study on Identifying the Correlation between Fourth Graders' Attitudes and Behaviors toward the Environment
}

\author{
Mehmet Akif Haşıloğlu ${ }^{1} \&$ Ayşe Kunduraci ${ }^{2}$ \\ ${ }^{1}$ Education Faculty, Ağrı İbrahim Çeçen University, Turkey \\ ${ }^{2}$ M.E.B, Teacher of Science, Turkey \\ Correspondence: Mehmet Akif Haşıloğlu, Education Faculty, Ağrı İbrahim Çeçen University, Ağrı, Turkey. Tel: \\ 90-505-746-8536. E-mail: mehmet.hasiloglu@hotmail.com
}

$\begin{aligned} & \text { Received: December 7, } 2017 \quad \text { Accepted: January 12, } 2018 \\ & \text { doi:10.5539/ies.v11n6p60 }\end{aligned} \quad$ URL: https://doi.org/10.5539/ies.v11n6p60

\begin{abstract}
This study aims to examine the degree to which scores received by fourth graders in Turkey on the environmental attitudes scale is reflected in their environmental awareness (with respect to practice, behaviors), and to identify the correlation between attitudes and behaviors. Case study design was used to collect data in the study. Observation and questionnaire techniques were used as the data collection instruments. The sample of the study consisted of 15 students selected among the fourth graders attending elementary schools in Ağrı province of Turkey in the 2015-2016 academic year. The Attitudes Toward the Environment Scale (ATES), developed by Yaşaroğlu (2012), was used to measure students' attitudes toward the environment. The reliability of the scale was examined by Yaşaroğlu (2012) using Cronbach's alpha internal consistency coefficient, which is reported to be 0.84 . Observations were made to measure students' environmental awareness by using the video recording technique. On the other hand, Spearman's Correlation analysis was used for data analysis. The relationship between students' scores on the attitude scale and their scores for environmental awareness, assigned on the basis of the observations made, was found weak, as indicated by the correlation between the two (Spearman's rho $(r)=0,075)$. An important finding was that even though students received satisfactory scores on the ATES scale, a sizable number of them failed to reflect these attitudes in their practices or behaviors, which would indicate environmental awareness.
\end{abstract}

Keywords: environment, environmental education, environmental awareness, attitudes and behaviors

\section{Introduction}

The environment refers to the physical, biological, social, economic and cultural milieu in which humans and other species maintain relationships and interact with one another throughout their lives. Environment is anything affecting humans. Humans are also part of the environment. As social beings, humans engage in various relationships and interactions in their social environment as integral parts of the society. The environment refers to all systems that affect people, be they social, physical, chemical or biological, among others (Yiğit \& Bayrakdar, 2016). People's interaction with their environment starts the moment they are conceived, and continues until the end of their lives.

Science and technology are making great progress in our age. In this regard, the human population and its needs are also on the increase. Thus, Türküm (1998) describes the interaction between humans and the environment as follows: "The relationship human beings have with the nature is as old as their existence on earth; it first started in the form of efforts to make use of the nature, and then, parallel to scientific development, turned into efforts to dominate nature." These efforts resulted in environmental pollution, one of the biggest contemporary problems. Environmental pollution has gradually reached unprecedented levels, started to harm human health, and significantly disturbed the natural balance (Demirbaş \& Pektaş, 2009). "Concerns about environmental problems led, especially after 1970s, to international efforts to prevent these problems (1972 UN Conference on the Human Environment, 1982 UN report Our Common Future, 1992 Rio Summit, etc.). The 1977 Tbilisi Declaration is considered to be a turning point in environmental education, because it provided detailed guidelines on the nature, objectives, and scientific foundation of environmental education at both national and international levels. The Tbilisi Declaration divides objectives of environmental education into five categories: awareness, knowledge, attitudes, skills and participation. After this declaration, efforts on environmental 
education focused on how to achieve these objectives" (Gökçe et al. 2007).

In terms of knowledge, biological, physiological and socioeconomic roles and factors need to be taught via education (UNESCO-UNEP, 1978:6). Environmental education is based on the idea of protecting the nature and natural resources. Environmental education should affect human behavior, in addition to providing knowledge. The main objective of environmental education is to effect positive and sustained behavioral change, and to ensure active participation of individuals in the solution of problems (Şimşekli, 2004). Discomfort resulting from the loss of resources over time and being deprived of pleasures of nature led people to take measures to avoid repeating their past mistakes. In this sense, contemporary environmental awareness is arguably on the rise (Türküm, 1998). Education for environment aims to educate individuals who are aware of local, regional, national and global problems, care about and pay attention to these problems, voluntarily make efforts for the solution of these problems, and have ecological culture, strong environmental ethics and high environmental awareness (Atasoy \& Ertürk, 2008).

In the process of education, defined as limited behavioral change in the desired direction, skills, attitudes and habits play an important role. In the context on environmental problems, an important factor that affects whether people display behaviors expected of them is attitudes, including enjoying, caring for, and respecting the environment one lives in. Haşıloğlu, Keleş, and Aydın (2011), in a study in which they examined environmental awareness among sixth, seventh and eighth graders in relation to a number of variables, found that students in higher graders had less positive behaviors toward the environment. According to Kağıtçıbaşı (2010), "Attitude is a tendency that is attributed to an individual and that regularly shapes their thoughts, feelings and behaviors toward a psychological object." Poortinga, Steg, and Vlek (2004) report that besides knowledge, characteristics such as interest and attitudes affect individuals' behaviors toward the environment. Environmental education provides environment-related knowledge, but it also tries to develop positive attitudes toward the environment and turn these attitudes into behavior. Environmental education addresses cognitive, sensual and psycho-motor aspects of students (Unterbruner, 1991).

There is an important relationship between attitudes and behaviors. Attitude is an abstract concept, and it is concretized via behaviors. Attitude can also be described as the will that underlies human behavior and that has the capacity to shape our behaviors. Many studies have been conducted on environmental attitudes. Among the vast literature on the issue; several studies are conducted for various levels. Kilbourne, Beckmann, Lewis, and Dam (2001) and Özmen, Çetinkaya, and Nehir (2005) studied the case for university students; Yılmaz, Bone and Andersen (2004) and Gökçe, Kaya, Aktay, and Özden (2007) studied the elementary students' views on environmental issues; Hacıeminoğlu, Alp, and Ertepınar (2006) investigated teacher candidates' for the same issue; Yaşaroğlu (2012) studied the topic at primary students' level. However, we were unable to find an in-depth study that measures environmental awareness by examining whether environmental attitudes are reflected in behaviors as well. The present study aims to fill this gap and identify the correlation between attitudes and behaviors.

\section{Methodology}

This study examines the degree to which scores received by fourth grade students on the environmental attitudes scale are reflected in their environmental awareness (practices and behaviors). To this end, a case study design was preferred.

As an illustrative case study, current research is devoted to exploring the correlation between fourth grader elementary students' attitudes and behaviors towards the environment through an attitude scale and observations conducted by the researcher himself. The case has been investigated as a cross-sectional study with fifteen fourth grader elementary students in Turkish public school. The researcher preferred case study because this study design enables investigating a special case with a small sample group in depth in a short time span. Both qualitative and quantitative data sets can be used for this sort of case studies (Hitchcook \& Hughes, 1995; Merriam, 1998; Marshall \& Rossman, 1999; Çepni, 2001).

For data collection, first, the 31-item Attitudes Toward the Environment Scale (ATES) was used, developed by Yaşaroğlu (2012) to measure fourth graders' attitudes toward the environment. The reliability of the scale was examined by Yaşaroğlu (2012) using Cronbach's alpha internal consistency coefficient, which is reported to be 0.84.Then, to see whether environmental awareness is reflected in behaviors, we made observations making use of the video recording technique. "The items basically cover the topics of 'general environmental awareness, water, energy, animals, recycling, and pollution'. ATES consists of Likert-type items in which answers consist of selecting a point from a range. ATES was evaluated by assigning a score of 3 to the most positive option and a score of 1 to the most negative option. Statements on the scale were followed by three options: 'Agree (3)', 
'Somewhat agree (2)', and 'Disagree (1)'. For items that contained negative statements, the codding was reversed. For these items, the coding was as follows: 'Agree (1)', 'Somewhat agree (2)', and 'Disagree (3)'." (Yaşaroğlu, 2012). To measure, using the video recording technique, whether students' environmental awareness is reflected in their behaviors, chocolate bars was handed out to students in the classroom, and mandarins in the school yard. Students knew about the video recording, but did not know that the recording was made to observe whether their environmental awareness was reflected in their behaviors. Three people were assigned to make the video recordings so that the behaviors could be observed. Videos were analyzed with the help of a teacher and two researchers. Behaviors displayed by the students were categorized and the authors developed a video recording evaluation scale. This scale is reported in Table 1.

Table 1. Video recording evaluation scale

\begin{tabular}{ccccc}
\hline $\begin{array}{c}\text { Throws trash on the } \\
\text { ground in both } \\
\text { situations }\end{array}$ & $\begin{array}{c}\text { Gives trash } \\
\text { to others }\end{array}$ & $\begin{array}{c}\text { Throws trash in the trash can when in the } \\
\text { classroom, and on the ground when in the } \\
\text { school yard }\end{array}$ & $\begin{array}{c}\text { Throws trash in the } \\
\text { trash can in both } \\
\text { situations }\end{array}$ & $\begin{array}{c}\text { Throws trash in the trash can in } \\
\text { both situations and warns } \\
\text { classmates }\end{array}$ \\
\hline 0 POINTS & 1 POINT & 2 POINTS & 3 POINTS & 4 POINTS \\
\hline
\end{tabular}

\section{Sample}

The sample of the study consisted of 15 students selected among the fourth graders attending elementary schools in Ağrı province of Turkey in the 2015-2016 academic year. The sampling group is restricted to a small number $(\mathrm{N}=15)$ as the study has a qualitative part in which all students were simultaneously video recorded for their behaviors to be observed. In order to observe the behaviors of the sample group at the same time, only 15 students were included in the study.

\section{Findings and Comments}

This section presents findings and comments on the scores received by students on the attitude scale and the video recording evaluation scale.

\subsection{Findings and Comments on Scores on the Attitudes toward the Environment Scale}

Scores received by the students on the Attitudes Toward the Environment Scale, developed by Yaşaroğlu (2012), were calculated by the researchers. These scores are reported in Table 2. Scores ranged between a minimum of 69 and a maximum of 79. The arithmetic mean of the scores received by 15 students was 75.6. This finding shows that fourth graders who participated in the study received satisfactory scores from the ATES. People who have negative attitudes toward the environment would not care about environmental problems and contribute to the worsening of environmental problems (Sağlam \& Uzun, 2006). Students who have positive attitudes toward the environment, on the other hand, are expected to care about environmental problems. The positive attitudes they have should be reflected in their behaviors as well.

\subsection{Findings and Comments on Scores on the Video Recording Evaluation Scale}

In the next stage following the attitude scale, observations were made to see what students would do with the wrappers of the chocolate bars handed out in the classroom and the peels of the mandarins handed out in the school yard. Students' behaviors were observed with the help of video recording devices. Observation of what students would do with the chocolate bar wrappers and mandarin peels handed out was made without knowing their individual scores on the attitude scale.

S2, S3, S4, S5 and S7 were observed to deposit their trash in the trash can in both situations. S1, S15, S14 and S13 were observed to deposit chocolate bar wrappers in the trash can when in the classroom, but throw mandarin peels on the ground when in the school yard. S6 and S11 kept the chocolate bar wrappers in their hand or pocket, respectively, when in the classroom, and deposited them in the trash can together with the mandarin peels when in the school yard. S9 and S10 left chocolate bar wrappers on their desks, and threw mandarin peels on the ground. S12 not only deposited the trash in the trash can in both situations, but also warned classmates who failed to do so.

\subsection{Findings and Comments on the Students' Environmental Attitudes and the Behaviors They Display}

This section presents the scores students received on the ATES and the video recording evaluation scale, based on their behaviors. Scores received by the students are reported in Table 2. 
Table 2. Scores received by students on the ATES and the video recording evaluation scale

\begin{tabular}{lccccccccccccccc}
\hline Students & S1 & S2 & S3 & S4 & S5 & S6 & S7 & S8 & S9 & S10 & S11 & S12 & S13 & S14 & S15 \\
\hline Scores received on the ATES & 77 & 79 & 74 & 74 & 79 & 75 & 74 & 79 & 75 & 74 & 69 & 77 & 76 & 75 & 77 \\
Scores received on the video recording evaluation scale & 2 & 3 & 3 & 3 & 3 & 3 & 3 & 4 & 0 & 0 & 3 & 1 & 2 & 2 & 2 \\
\hline
\end{tabular}

Table 2 shows that $\mathrm{S} 8$, who received the highest score on the attitude scale, also received the highest score on the video recording evaluation scale, reflecting their attitudes in their behavior, indicating environmental awareness. S11, who received the lowest score on the attitude scale, nevertheless received a high score on the video recording evaluation scale. On the other hand, S9 and S10, whose scores on the attitude scale were higher than some other students, received the lowest scores on the video recording evaluation scale. S12 received the second highest score on the attitude scale, but received a low score on the video recording evaluation scale. S1, S13, S14 and S15 had above-average attitude scores, but their behavior scores were mediocre. S2, S3, S4, S5, S6 and S7 were found to receive high scores for the behaviors they displayed, paralleling their attitude scores.

\subsection{Findings and Comments on the Correlation between Attitudes and Behaviors}

Spearman's correlation analysis was used to identify the correlation between the scores students received on the attitude scale and their observed behaviors concerning environmental awareness. Results of the analysis are reported in Table 3.

Table 3. Spearman's correlation analysis

\begin{tabular}{lcccc}
\hline & Attitude & \multicolumn{2}{c}{ Behavior } \\
\hline \multirow{4}{*}{ Spearman's rho } & Correlation Coefficient & 1.000 & .075 \\
\cline { 2 - 5 } & & Sig. (2-tailed). & & .791 \\
& \multirow{3}{*}{ behavior } & Correlation Coefficient & .075 & 1.000 \\
& & Sig. (2-tailed) & .791 & \\
& & $\mathrm{~N}$ & 15 & 15 \\
\hline
\end{tabular}

Table 3 shows that Sig.(2-tailed) $=0.791$. This value is higher than 0.05 , indicating that there is no significant relationship between the scores students received on the attitude scale and their observed behaviors concerning environmental awareness. Spearman's rho ( $\mathrm{r}$ ) was found to be 0.075 . This value is "between 0 and 0.5 , indicating a weak relationship or no relationship".

\section{Discussion and Conclusion}

The mean score fourth grade students received on the ATES was 75.6. This mean score on a 31-item attitude scale is relatively high. Students were observed to see whether their environmental awareness was reflected in their practices or behaviors. Analysis of the video recordings made to this end showed that despite receiving satisfactory scores on the ATES, a significant number of students failed to reflect this attitude in their practices or behaviors, which would indicate environmental awareness. This can be caused by the fact that students may not give sincere responses to the ATES items. As a result, their attitude results are not reflected in their behaviors. Sağır, Aslan, and Cansaran (2008) found that though the students are educated in terms of environment they do not participate in the activities related to environment. That is to say, some students failed to transfer the environmental attitudes they had at a cognitive level into psycho-motor skills. Spearman's correlation analysis conducted to identify the correlation between attitudes and behaviors showed that the Spearman's rho coefficient was 0.075 . Because this value is between 0 and 0.5 , it indicates that the relationship is weak or there is no correlation. In the same analysis, the two tailed significance value $(0.791)$ was found to be above 0.05 , indicating that there is no significant relationship between attitudes and behaviors. There are several studies reporting the relationship between attitude and behavior towards the environment. Hemliech and Ardoin (2008) point out the negative relationship between attitudes and behaviors. That is, the individuals do not reflect the behaviors reported in their attitudes regarding the environment. There are several other studies showing the insufficient level of coherence between attitudes and behaviors (Arbuthnott, 2009; Szerenyi et al., 2011; Zsoka et al., 2013). Also some studies found powerful predictors in positive way regarding the attitudes and behaviors towards the environment (Bamberg \& Möser, 2007; Kaiser et al., 2007; Levine \& Strube, 2012; Rodríguez-Barreiro et al., 2013). 
Overall, these findings show that students had satisfactory levels of environmental attitudes, but had problems reflecting these attitudes in their behaviors. Future studies should probe into the reasons why this might be the case. Studies should also explore ways to support students as they reflect their environmental attitudes in their behaviors. Most studies on environmental attitudes and behaviors use "Behavioral scales" as the data collection instrument. It is recommended, to improve the reliability of the scales, that they be accompanied by observation.

\section{References}

Arbuthnott, K. D. (2009). Education for sustainable development beyond attitude change. International Journal of Sustainability in Higher Education, 2, 152-163. https://doi.org/10.1108/14676370910945954

Atasoy, E., \& Ertürk, H. (2008). A survey of primary school students on environmental attitudes and environmental knowledge. Journal of Erzincan Education Faculty, 10(1), 105-122.

Bamberg, S., \& Möser, G. (2007). Twenty years after Hines, Hungerford, and Tomera: A new meta-analysis of psycho-social determinants of pro-environmental behaviour. Journal of Environmental Psychology, 1, 14-25. https://doi.org/10.1016/j.jenvp.2006.12.002

Çepni, S. (2001). Araştırma ve proje çalı̧̧malarına giriş. Trabzon: Erol Ofset Matbaacılık.

Demirbaş, M., \& Pektaş, H. M. (2009). The level of primary school students' realization of basic concepts related to environmental problem. Journal of Necatibey Faculty of Education Electronic Science and Mathematics Education, 3(2), 195-211.

Gökçe, N., Kaya, E., Aktay, S., \& Özden, M. (2007). Attitudes of elementary school students towards the environment. Elementary Online, 6(3), 452-468.

Hacıeminoğlu, E., Alp, E., \& Ertepınar, H. (2006). Teacher candidates' attitudes towards teaching environment and environment. VII. National Science and Mathematics Education Congress Abstract Book (pp. 7-9).

Haşıloğlu, M. A., Keleş, P. U., \& Aydın, S. (2011). Examining environmental awareness of students from 6th, 7th and 8th classes with respect to several variables:"sample of Agri city". Procedia-Social and Behavioral Sciences, 28, 1053-1060. https://doi.org/10.1016/j.sbspro.2011.11.191

Heimlich, J. E., \& Ardoin, N. M. (2008). Understanding behavior to understand behavior change: A literature review. Environmental Education Research, 14(3), 215-237. https://doi.org/10.1080/13504620802148881

Hitchcock, G., \& Hughes, D. (1995). Research and teacher a qualitative introduction to school-based reseach (2nd ed.). New York: Routhledge Publication.

Kağıtçıbaşı, Ç. (2010). Person and people in today: Introduction to social psychology (12th ed.). Istanbul: Evrim Publishing House.

Kilbourne, W. E., Beckmann, S. C., Lewis, A., \& Dam, Y.V. (2001). A multinational examination of the dominant social paradigm in environmental attitudes of university students. Environment \& Behavior, 33(2), 209-229. https://doi.org/10.1177/00139160121972954

Levine, D. S., \&, Strube, M. J. (2012) Environmental attitudes, knowledge, intentions and behaviors among college students. The Journal of Social Psychology, 3, 308-326. https://doi.org/10.1080/00224545.2011.604363

Marshall, C., \& Rossman, G. B. (1999). Designing qualitative research (3rd ed.) London: Sage Publications.

Merriam, S. B. (1998). Qualitative research and case study applications in education. San Francisco: Jossey-Bass Publishers.

Özmen, D., Çetinkaya, A. Ç., \& Nehir, S. (2005). University students' attitudes towards environmental problems. TAF Preventive Medicine Bulletin, 4(6), 330-344.

Pooley, J. A., \& O'Connor, M. (2000). Environmental education and attitudes. Environment \& Behavior, 32(5), 711-724. https://doi.org/10.1177/0013916500325007

Poortinga, W., Steg, L., \& Vlek, C. (2004). Values, environmental concern, and environmental behavior: A study into household energy use. Environment and Behavior, 36(1), 70-93. https://doi.org/10.1177/0013916503251466

Rodríguez-Barreiro, L. M., Fernandez-Manzanal, R., Serra, L. M., Carrasquer, J., Murillo, M. B., Morales, M. J., ... Del Valle, J. (2013). Approach to a causal model between attitudes and environmental behavior: A graduate case study. Journal of Cleaner Production, 48, 116-125. https://doi.org/10.1016/j.jclepro.2012.09.029 
Sağır, Ş. U., Aslan, O., \& Cansaran, A. (2008). The examination of elementary school students 'environmental knowledge and environmental attitudes with respect to the different variables Elementary Education Online, 7(2), 496-511. https://doi.org/10.17051/ilkonline.2017.342960

Şimşekli, Y. (2004). Sensitivity of primary schools to environmental education activities for the development of environmental awareness. Uludăg University Journal of Education Faculty, 17(1), 83-92.

Szerenyi, Z., Agnes, Z., \& Anna, S. (2011). Consumer behaviour and lifestyle patterns of Hungarian students with regard to environmental awareness. Society and Economy, 33(1), 89-109. https://doi.org/10.1556/SocEc.33.2011.1.8

Türküm, A. S. (1998). Environmental problems and environmental awareness in contemporary society. contemporary life contemporary human. Anadolu University Open Teaching Faculty, Primary Education Teacher's Degree Completion Program, Eskişehir (pp. 165-181).

UNESCO-UNEP. (1978). Intergovernmental conference on environmental education Tiblisi (ussr) "Final report". Paris.

Unterbruner, U. (1991). Umwelterziehung und die Ängste jugendlicher vor Umweltzerstörung. In G. Eulefeld, \& D. S. H. Bolscho (Eds.). Umweltbewusstsein und Umwelterziehung. Kiel.

Uzun, N., \& Saglam, N. (2006). Development and validation of environmental attitude scale for secondary school students. Journal of Hacettepe University Education Faculty, 30, 240-250.

Yaşaroğlu, C. (2012). Evaluation of attitudes and behaviors towards first stage primary school students (Unpublished doctoral dissertation). İnönü University, Malatya, Turkey.

Yiğit, B., \& Bayrakdar, M. (2016). School-environment relationship. Ankara: Pegem A Publication.

Y1lmaz, O., Boone, W., \& Andersen, H. O. (2004). Views of elementary and middle school Turkish students toward environmental issues. International Journal of Science Education, 26(12), 1527-1546. https://doi.org/10.1080/0950069042000177280

Zsoka, A., Szerenyi, Z. M., Szechy, A., \& Kocsis, T. (2013). Greening due to environmental education? Environmental knowledge, attitudes, consumer behavior and everyday pro-environmental activities of Hungarian high school and university students. Journal of Cleaner Production, 48, 126-138. https://doi.org/10.1016/j.jclepro.2012.11.030

\section{Copyrights}

Copyright for this article is retained by the author(s), with first publication rights granted to the journal.

This is an open-access article distributed under the terms and conditions of the Creative Commons Attribution license (http://creativecommons.org/licenses/by/4.0/). 